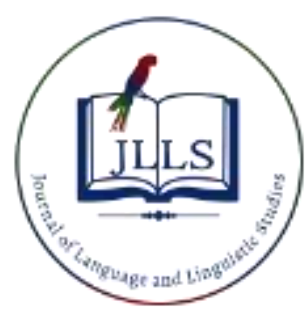

Available online at www.jlls.org

JOURNAL OF LANGUAGE AND LINGUISTIC STUDIES

ISSN: $1305-578 \mathrm{X}$

Journal of Language and Linguistic Studies, 16(1), 405-417; 2020

\title{
An analysis of innovative Lean Method in foreign language learning
}

\author{
Filiz Yalçın Tilfarlıoğlu a 1 \\ ${ }^{a}$ Gaziantep University, Şehitkamil Gaziantep 27310, Turkey
}

\section{APA Citation:}

T1lfarlığlu, F.Y., (2020) An analysis of innovative Lean Method in language learning. Journal of Language and Linguistic Studies, 16(1), 405-417. Doi: $10.17263 /$ jlls. 712860

Submission Date:24/11/2019

Acceptance Date:14/01/2020

\begin{abstract}
The question of how to teach and learn English has been the preoccupation of many scholars of English Language Teaching for more than a century. Since the emergence of grammar translation method, researchers, teachers, and academicians have been trying to find the best method for their learners. In other words, this process can be defined as a century of questioning. In fact, some of the methods have been successful to some extend in the mastery of language, but most of them unfortunately cannot even reach the promised lands of the fruitful learning, and none of them were completely suitable for all types of the learners. There are several reasons behind this problem, and one of them could be the students' contribution in the creation of these methods. It has been rarely questioned that how students feel about these methods employed in English classes, despite the fact that these methods, namely innovations, have been created for the purpose of students' mastery of foreign language learning. This study is mainly focused on using quantitative design conducted with 975 students and participants were randomly selected from 3 universities, 5 high schools, 2 middle schools and 1 primary school in Turkey and Iraq in order to analyze the suitability of English instruction from the perspective of learners towards innovative lean method. Within the context of the study, the students' attitudes and opinions towards innovative Lean Educational method were revealed and some recommendations were developed for especially language teachers and researchers.
\end{abstract}

(C) 2020 JLLS and the Authors - Published by JLLS.

Keywords: Innovation Lean Educational Method; Foreign Language Learning; English Language Teaching.

\section{Introduction}

Throughout the history teaching of the foreign languages has had special importance and educators have given utmost care to this issue in order to teach them properly and to help their students master the target language. Nowadays, with the requirements of the globalized world, English has become the dominant language of commerce, media and education. In other words, English has been "by far the most widely used of all living languages" and it has been taught as foreign language at schools throughout the world (Broughton, Brumfit, Flavell, Hill, Pincas, 2003). As a result, the concept of methods and techniques has gained the role of the key of successful delivery of English and the quest for better methods and techniques has been the preoccupation of many teachers and professors for more

\footnotetext{
${ }^{1}$ Corresponding author. Tel.: +90-535-257-6736

E-mail address: fyalcin@gantep.edu.tr
} 
than a century. Since the invention of grammar translation method, ELT world has witnessed quite a number of methods such as series method, direct method, audio-lingual method, total physical response, suggestopedia, communicative language teaching, task-based language teaching, content based instruction, whole language education, post-method etc. In addition, it has been observed that different methods have come into existence in reaction to the inadequacies of the earlier methods in fulfilling the needs of the learners (Brown, 2007).

\subsection{Literature Review}

Following the evolution of different methods, different techniques have emerged in the field of ELT in line with the method that they have connection. Although, some of these methods and techniques can be identified as successful ones almost none of them couldn't meet the different needs of different types of the learners. In other words, no method or technique has reached the promised lands of limitless success for everyone. One of the reasons behind this situation is methods are "fixed set of classroom practices that serve as a prescription" (Bell, 2003, p.326). In other words the creators of methods acted like doctors and formulized some classroom activities for language lessons, and they hoped that if these set of rules are followed properly, there would be successful mastery of the target language by all learners, but complete learning of language were not easy and simple like that and most of the methods and techniques failed because of this overgeneralization. Secondly, another reason behind this problem is the dichotomy between theory and practice (Kumaravadivelu, 2006). Generally, the theories are created by academicians and they are employed in the language classrooms by teachers. Unfortunately, the relationship between theorists and practitioners is quite similar to the relationship between producers and customers in most cases (Hedgcock, 2002). As a result, like in every reciprocal interest situations, most of the methods and techniques cannot become successful in the long run.

Teaching profession actually requires a different connection between theorists and practitioners unlike in the example of salesman and customer. In other words, it requires the cooperation of both teachers and professors. Fortunately, "action research" and classroom based research have been proposed to overcome this dilemma by some researchers (Bailey, 2001; Johnson, 1999; McKay, 2006; Murphy, \& Byrd, 2001). Additionally, it has been observed that thanks to these new research types, the problem has solved to some extent, but it has been not solved completely, because efforts to improve the effectiveness of language teaching have often focused on changes in teaching methods and in the creation process of these methods and techniques, the attention point has always been the learners' needs, but there is almost no study which focuses on students' considerations towards the methods and techniques employed in English lessons.

Since the creation of a successful learning atmosphere requires the cooperation of all school components, which are students, teachers, parents and school administrations, this study tries to reveal most recent considerations and implications by investigating the students' considerations towards the Lean Educational Method employed in English lessons. Lean Educational Method, which are based on continuous improvement principle, can be defined as a culture and value system that aims to eliminate money and time wastes by adding value to the processes that it serves. Lean is successfully applied by many manufacturing companies, especially, in industry for a long time. In education, purpose of Lean is to balance the curriculum, which is not completed due to various reasons, by eliminating wastes. Therefore, a balanced curriculum facilitates (1) developing an effective education process and (2) performing complete learning of students. Thus, in Lean philosophy, continuous improvement is aimed. In this study, Lean methods, which are developed with teachers and students, believed to provide significant benefit to the students' achievement and effective teaching skills of teachers (Cleary, \& Duncan, 1997, 2008; Connell, 2005; Dennis, 2007; DuFour, \& Eaker, 2005; Eaker, \& DuFour, 2015; Ewy, 2009; Fitzgerald, 2006; George, \& George, 2003; Jenkins, 2003, 2013; Jenkins, Roettger, \& 
Roettger, 2007). In this context, education domain is quite new and Lean practices have showed that added-value can be achieved by maintaining high level of awareness, reducing school costs, reducing preparation time in work, continuously improving wastes and facilitating the flow of processes in a planned way. In Lean education, which is an organizational improvement and change program, the main objective is to increase efficiency. The problems encountered in the process are not only considered just as problems, but also they are considered as opportunities which will facilitate changes.

\subsection{Research Question}

In problem solving component of Lean Educational Method, the processes like; transparency, participation, speed and equal learning are extremely important. Additionally, this study gives some clues about how to form efficient classroom practices by providing some practical implications for foreign language teaching. In order to achieve these aims the following is the research question of the study:

Do students take the Lean methods into consideration:
a. before the lesson?
b. while preparing for the lesson?
c. in their learning of the language?
d. after the lesson?

\section{Method}

Within the context of this study, descriptive analysis was carried out. After the analysis of the questionnaires, semi-structured and focus group interviews were carried out.

\subsection{Sample/Participants}

The study was conducted at University of Zakho at which students' mother tongues are Arabic and Kurdish ( $\mathrm{N}=100, \mathrm{M}=45, \mathrm{~F}=55, \mathrm{~A}=18-24)$, University of Duhok at which students' native languages are Arabic and Kurdish ( $\mathrm{N}=75, \mathrm{M}=37, \mathrm{~F}=38, \mathrm{~A}=18-25)$, Soran University at which students' mothertongues are Arabic and Kurdish ( $\mathrm{N}=80, \mathrm{M}=37, \mathrm{~F}=43, \mathrm{~A}=18-26)$, Diclekent Private High School in Diyarbakır $(\mathrm{N}=70, \mathrm{M}=33, \mathrm{~F}=37, \mathrm{~A}=16-17)$, Kani High School at which students' mother tongues are Arabic and Kurdish ( $\mathrm{N}=90, \mathrm{M}=43, \mathrm{~F}=47, \mathrm{~A}=15-16)$, Khak High School at which students' native languages are Arabic and Kurdish $(\mathrm{N}=85, \mathrm{M}=47, \mathrm{~F}=38, \mathrm{~A}=16-18)$, Shahid Burhan High School at which students mother tongues are Arabic and Kurdish (N=75, M=38, F=37, A=16-17), Duhok High School in DuhokIraq at which students' native languages are Arabic and Kurdish $(\mathrm{N}=100, \mathrm{M}=50, \mathrm{~F}=50, \mathrm{~A}=16-18)$, Akkent Middle School ( $\mathrm{N}=100, \mathrm{M}=47, \mathrm{~F}=53, \mathrm{~A}=12-14)$, Nurel Enver Taner Middle School in Gaziantep $(\mathrm{N}=100, \mathrm{M}=56, \mathrm{~F}=44, \mathrm{~A}=10-12)$, Ayşe Mustafa Sevcan Primary School (N=100, M=52, F=48, A=10$11)$.

\subsection{Instruments}

For the interviews, twenty students were chosen randomly from the institutions which are located in both Turkey and Iraq. The questionnaires allowed gathering information about students' considerations about Lean methods in English lessons regarding the following items: using different educational materials, giving homework, coming to the language classes prepared, giving annual and weekly programs, finishing the curriculum providing enough time and care to students by teachers; making daily 
plans, coming to the class prepared, sleeping after the new learnt material, using the school's facilities by students, organizing the course materials, making announcements from school's bulletin boards, repairing classes without delay, providing help to students by schools administrations

\subsection{Data collection procedures}

The participants were placed at appropriate levels from beginner to pre-intermediate level at the beginning of the academic year. The age of the participants vary from 10 to 26 years old. 485 of the participants were male and 490 of the participants were female at total. In order to identify the interview participants criterion sampling was used (Patton, 1990).

\subsection{Data analysis}

The pilot study of the questionnaire was carried out with 1804 students and the cronbach's alpha reliability factor of the study was found to be .908 , this score is quite reliable and valid for Likert-type scales (Nunan, 1997). In the analysis of the items in the questionnaire Statistical Package for Social Sciences $20^{\text {th }}$ version (SPSS) was used. For every item in the questionnaire, frequencies and percentages were calculated. Chi-square tests were applied in order to find the significance of the distribution of the answers.

\section{Results}

In table 1, in order to analyze the data gathered from the questionnaires, percentages, frequencies, means, standard deviations and chi-square results are displayed. It has been seen that the mean score of Nurel Enver Taner Middle School was the highest when it was compared with Akkent Middle School and Ayşe Mustafa Sevcan Primary School. It shows that some of the public schools are more applicable to carry out Lean methods than other public middle schools and primary schools. Teaching English to learners has linguistic, psychological, cognitive, social and cultural objectives and Lean can meet all of them (Vural, 2013). Moreover, this situation could be attributed to schools' facilities and the neighborhoods of these institutions. Another important finding about the mean scores is that the institutions located in Turkey has greater mean than the educational institutions in Iraq, so it can be said that students, teachers and school administrators in Turkey have greater tendency to execute Lean methods in the school processes. In Ayşe Mustafa Sevcan Primary Schhol, all of the chi-square findings were significant at $\mathrm{p}<.01$ level except the $10^{\text {th }}$ and the $44^{\text {th }}$ items. These items were significant at $\mathrm{p}<.05$ level. When the findings were analyzed in Akkent Middle School, except the items 9 and 11, all of the items were significant at $\mathrm{p}<.01$ level, the $9^{\text {th }}$ item was significant at $\mathrm{p}<.05$ level, but in the $11^{\text {th }}$ item no significance has been found out. Additionally, in Nurel Enver Taner Middle school except the items 15 and 34, all of the findings were significant at $p<.01$ level. In item 9 , the finding was significant at $p<.05$, but in item 34 no significance has been observed. When the data collected from high school contexts is analyzed, it can be clearly seen that all of the findings collected from Khak High school were significant at $\mathrm{p}<.01$ level. This finding was quite similar in Shahid Burhan High School, but in items 7, 20, 23, 24, 26,30 the significance level was $\mathrm{p}<.05$. The chi-square results in Kani High School were significant at $\mathrm{p}<.01$ and $\mathrm{p}<.05$ level. For questions 17, 25, 35, 43, 44, 46 the significance level all found at $\mathrm{p}<.05$, but in questions 4, 22, 24 and 36 no significance was seen. In Dicle Kent Private High School all of the findings were at $\mathrm{p}<.01$ significance level, but in questions $7,26,33,34,35,36$ the significance level at $\mathrm{p}<.05$, and for the item 48 no significance has been seen. The findings collected from Duhok High school were significant at $\mathrm{p}<.01$ level except item 2, and for the items 48 and 49 no significance was seen. When the data collected from university contexts was analyzed, it was observant that the findings in 
University of Zakho were significant at $\mathrm{p}<.01$. This finding is quite similar in Soran University and Duhok University, but in Soran University only the item 2 was at $p<.05$ level, while in Duhok University only the item 36 was at $p<.05$ level. If these results were analyzed it can be seen that for the $4,11,22$, $24,34,36,48$ and 49 items, no statistical significance has been found. This situation can be attributed to preferences of the teachers and the students in the foreign language learning process and the availability of educational materials in different educational contexts. Additionally, in order to enhance the learners' vocabulary and grammar knowledge, there is a need for different activities to teach the same vocabulary item and there is a need for comprehensible and cognitively demanding input to teach the grammar items (Afshar \& Bagherieh, 2014). In other words, Lean can be helpful for teachers in achieving this overwhelming nature of vocabulary and grammar teaching of the foreign language.

Table 1. Items Related to the Considerations about Lean Methods
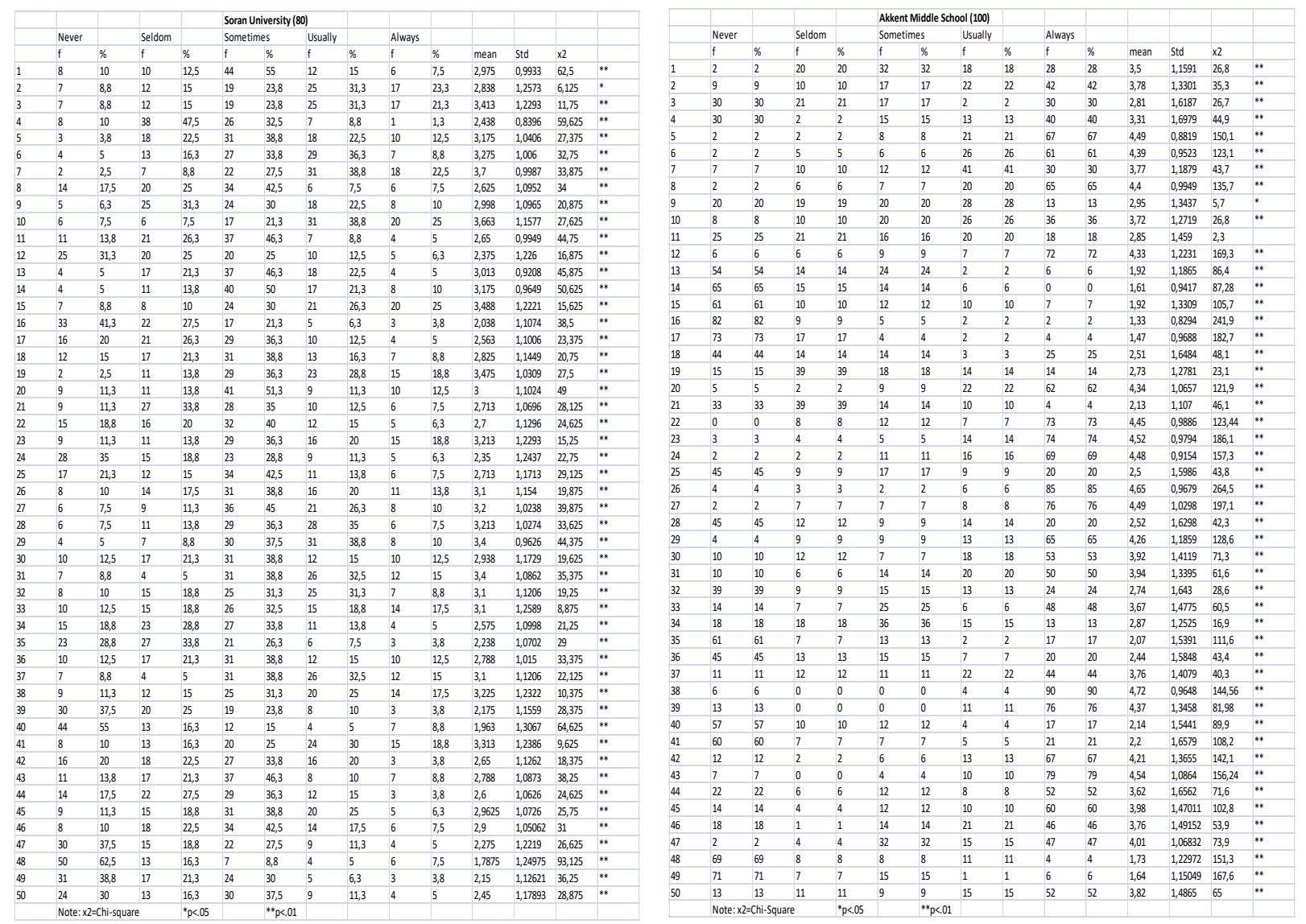

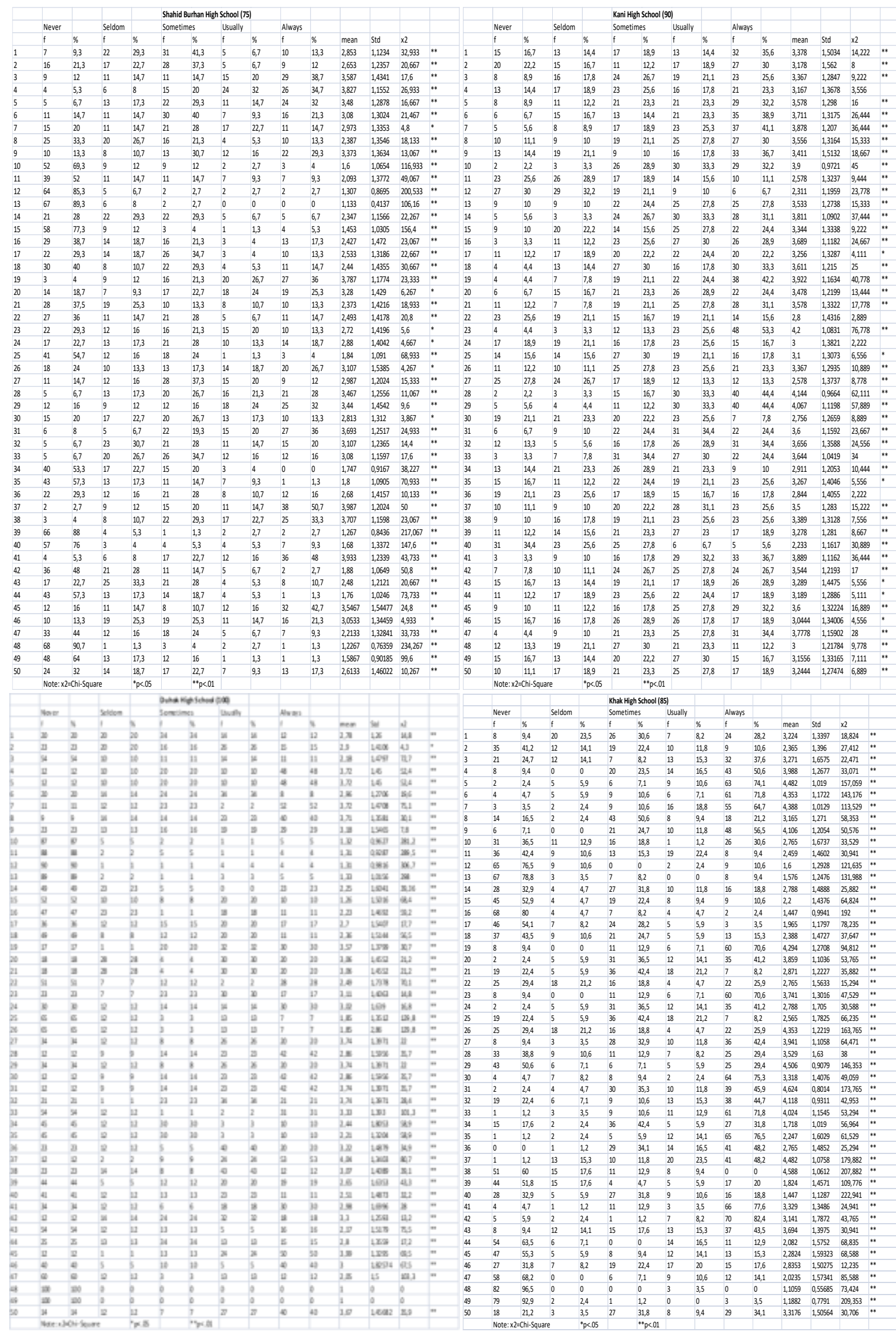


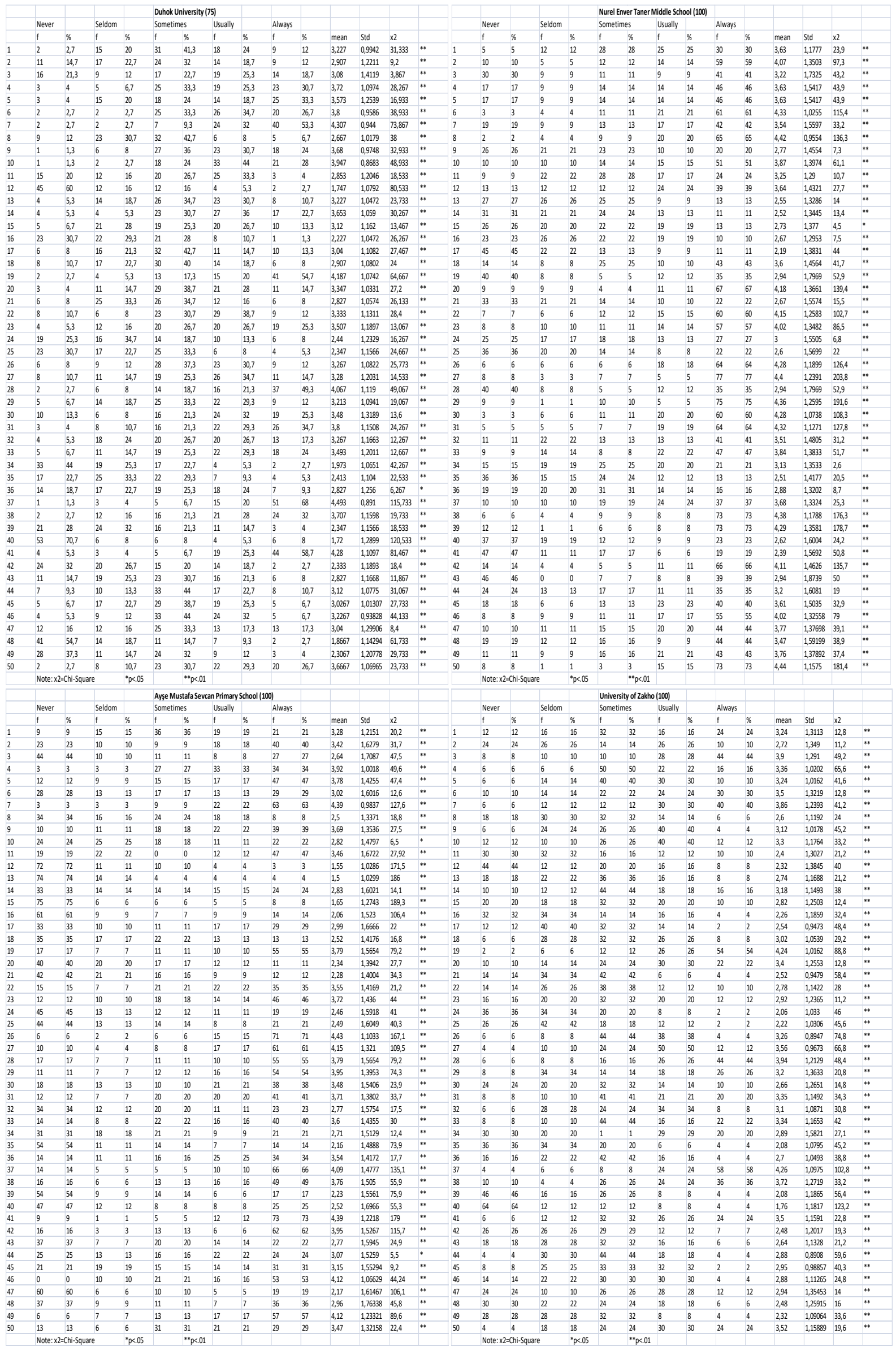




\begin{tabular}{|c|c|c|c|c|c|c|c|c|c|c|c|c|c|c|}
\hline & \multirow[b]{2}{*}{ Never } & \multirow[b]{3}{*}{$\%$} & \multirow{2}{*}{ Seldom } & & \multicolumn{4}{|c|}{ Didekent Private High School (70) } & \multirow{3}{*}{ Always } & \multirow[b]{3}{*}{$\%$} & \multirow[b]{3}{*}{ mean } & \multirow[b]{3}{*}{ std } & \multirow[b]{3}{*}{$x 2$} & \\
\hline & & & & & & & Usual & & & & & & & \\
\hline & $f$ & & & $\%$ & $f$ & $\%$ & $f$ & $\%$ & & & & & & \\
\hline 1 & 6 & 8,6 & 7 & 10 & 16 & 22,9 & 25 & 35,7 & 16 & 22,9 & 3,543 & 1,2001 & 17,286 & $*$ \\
\hline 2 & 0 & 0 & 3 & 4,3 & 21 & 30 & 24 & 34,3 & 22 & 31,4 & 3,929 & 0,8899 & 16,28 & $*$ \\
\hline 3 & 2 & 2,9 & 8 & 11,4 & 17 & 24,3 & 19 & 27,1 & 24 & 34,3 & 3,786 & 1,1279 & 22,429 & ** \\
\hline 4 & 5 & 7,1 & 15 & 21,4 & 25 & 35,7 & 16 & 22,9 & 9 & 12,9 & 3,129 & 1,1154 & 16,571 & $*$ \\
\hline 5 & 5 & 7,1 & 16 & 22,9 & 18 & 25,7 & 19 & 27,1 & 12 & 17,1 & 3,243 & 1,197 & 9,286 & $*$ \\
\hline 6 & 3 & 4,3 & 14 & 20 & 23 & 32,9 & 15 & 21,4 & 15 & 21,4 & 3,353 & 1,1551 & 14,571 & ** \\
\hline 7 & 7 & 10 & 15 & 21,4 & 17 & 24,3 & 17 & 24,3 & 14 & 20 & 3,229 & 1,276 & 4,857 & * \\
\hline 8 & 2 & 2,9 & 14 & 20 & 19 & 27,1 & 16 & 22,9 & 19 & 27,1 & 3,514 & 1,1764 & 14,143 & * \\
\hline 9 & 6 & 8,6 & 11 & 15,7 & 20 & 28,6 & 15 & 21,4 & 18 & 25,7 & 3,4 & 1,2672 & 9 & $*$ \\
\hline 10 & 6 & 8,6 & 12 & 17,1 & 21 & 30 & 18 & 25,7 & 13 & 18,6 & 3,286 & 1,2056 & 9,571 & $*$ \\
\hline 11 & 4 & 5,7 & 15 & 21,4 & 21 & 30 & 16 & 22,9 & 14 & 20 & 3,3 & 1, 1838 & 11 & $*$ \\
\hline 12 & 4 & 5,7 & 24 & 34,3 & 18 & 25,7 & 16 & 22,9 & 8 & 11,4 & 3 & 1,1293 & 18,286 & $* *$ \\
\hline 13 & 11 & 15,7 & 5 & 7,1 & 27 & 38,6 & 13 & 18,6 & 14 & 20 & 3,2 & 1,2921 & 18,571 & $*$ \\
\hline 14 & 6 & 86 & 25 & 357 & 15 & 214 & 12 & 171 & 12 & 171 & 2986 & 12568 & 13.857 & $*$ \\
\hline 15 & 4 & 5,7 & 13 & 18,6 & 21 & 30 & 18 & 25,7 & 14 & 20 & 3,357 & 1,1676 & 11,857 & $*$ \\
\hline 16 & 4 & 5,7 & 11 & 15,7 & 19 & 27,1 & 20 & 28,6 & 16 & 22,9 & 3,471 & 1,1761 & 12,429 & $* *$ \\
\hline 17 & 3 & 4,3 & 13 & 18,6 & 16 & 22,9 & 22 & 31,4 & 16 & 22,9 & 3,5 & 1,1641 & 13,857 & ** \\
\hline 18 & 5 & 7,1 & 14 & 20 & 20 & 28,6 & 20 & 28,6 & 11 & 15,7 & 3,257 & 1,1633 & 11,571 & $*$ \\
\hline 19 & 4 & 5,7 & 19 & 27,1 & 22 & 31,4 & 16 & 22,9 & 9 & 12,9 & 3,1 & 1,1184 & 15,571 & $* *$ \\
\hline 20 & 7 & 10 & 10 & 14,3 & 22 & 31,4 & 15 & 21,4 & 16 & 22,9 & 3,329 & 1,2594 & 9,571 & $* *$ \\
\hline 21 & 4 & 5,7 & 15 & $\begin{array}{l}\frac{145}{21,4} \\
2,4\end{array}$ & 19 & $\begin{array}{l}\mathbf{3}, 4 \\
27,1\end{array}$ & $\begin{array}{l}15 \\
16\end{array}$ & $\begin{array}{l}2,1,4 \\
22,9\end{array}$ & $\begin{array}{l}10 \\
16\end{array}$ & $\begin{array}{l}2,9 \\
22,9\end{array}$ & $\begin{array}{l}3,259 \\
3,357\end{array}$ & $\begin{array}{l}1,1354 \\
1,2163\end{array}$ & $\begin{array}{l}9,7 / 1 \\
9,571\end{array}$ & $*$ \\
\hline 22 & 6 & 8,6 & 19 & 27,1 & 21 & 30 & 13 & 18,6 & 11 & 15,7 & 3,057 & 1,2025 & 10,571 & $*$ \\
\hline 23 & 6 & 8,6 & 16 & 22,9 & 17 & 24,3 & 22 & 31,4 & 9 & 12,9 & 3,171 & $\begin{array}{l}1,1792 \\
1,1\end{array}$ & 11,857 & $*$ \\
\hline 24 & 4 & 5,7 & 9 & 12,9 & 22 & 31,4 & 17 & 24,3 & 18 & 25,7 & 3,514 & 1,1764 & 15,288 & $* *$ \\
\hline 25 & 5 & 7,1 & 13 & 18,6 & 21 & 30 & 18 & 25,7 & 13 & 18,6 & 3,3 & 1,1838 & 10,571 & $*$ \\
\hline 26 & 7 & 10 & 13 & 18,6 & 16 & 22,9 & 16 & 22,9 & 18 & 25,7 & 3,357 & 1,3192 & 5,286 & * \\
\hline 27 & 5 & 7,1 & 18 & 25,7 & 15 & 21,4 & 17 & 24,3 & 15 & 21,4 & 3,271 & 1,2617 & 7,714 & $* *$ \\
\hline 28 & 4 & 5,7 & 19 & 27,1 & 22 & 31,4 & 16 & 22,9 & 9 & 12,9 & 3,1 & 1,1184 & 15,571 & $*$ \\
\hline 29 & 1 & 1,4 & 14 & 20 & 23 & 32,9 & 18 & 25,7 & 14 & 20 & 3,429 & 1,071 & 19 & $*$ \\
\hline 30 & 5 & 7,1, & 9 & 12,9 & 22 & $\begin{array}{l}3,5 \\
31,4\end{array}$ & $\begin{array}{l}10 \\
19\end{array}$ & 27,1 & 15 & 21,4 & 3,429 & 1,1743 & 14 & $* *$ \\
\hline 31 & 5 & 7,1 & 18 & 25,7 & 12 & 17,1 & 13 & 18,6 & 22 & 31,4 & 3,414 & 1,3566 & 11,857 & $*$ \\
\hline 32 & 10 & 14,3 & 12 & 17,1 & 21 & 30 & 18 & 25,7 & 9 & 12,9 & 3,057 & 1,2381 & 7,857 & $*$ \\
\hline 33 & 10 & 14,3 & 20 & 28,6 & 17 & 24,3 & 12 & 17,1 & 11 & 15,7 & 2,914 & $\begin{array}{l}1,2937 \\
1,2\end{array}$ & 5,286 & * \\
\hline 34 & 8 & 11,4 & 18 & 25,7 & 18 & 25,7 & 11 & 15,7 & 15 & 21,4 & 3,1 & 1,3204 & 5,571 & * \\
\hline 35 & & 10 & 17 & 24,3 & 15 & 21,4 & 18 & 25,7 & 13 & 18,6 & 3,186 & 1,2774 & 5,429 & \\
\hline 36 & 9 & 12,9 & 11 & 15,7 & 17 & 24,3 & 18 & 25,7 & 15 & 21,4 & 3,271 & 1,3179 & 4,286 & * \\
\hline 37 & 4 & 5,7 & 12 & 17,1 & 18 & 25,7 & 22 & 31,4 & 14 & 20 & 3,429 & 1,1619 & 13,143 & $*$ \\
\hline 38 & 2 & 2,9 & 11 & 15,7 & 23 & 32,9 & 15 & 21,4 & 19 & 27,1 & 3,543 & 1,1381 & 18,571 & $*$ \\
\hline 39 & 5 & 7, & 11 & $\begin{array}{l}1, i, \\
15,7\end{array}$ & 21 & $\begin{array}{l}3,5 \\
30\end{array}$ & 23 & $\begin{array}{l}3,4,4 \\
322,9\end{array}$ & 10 & $\begin{array}{l}1,1, \\
14,3\end{array}$ & $\begin{array}{l}3,343 \\
3,314\end{array}$ & $\begin{array}{l}1,10101 \\
1,1234\end{array}$ & $\begin{array}{l}10,8717 \\
1,857\end{array}$ & $* *$ \\
\hline 40 & 5 & 7,1 & 16 & 22,9 & 17 & 24,3 & 16 & 22,9 & 16 & 22,9 & 3,314 & 1,2574 & 7,286 & $*$ \\
\hline 41 & 6 & 8,6 & 14 & 20 & 16 & 22,9 & 15 & 21,4 & 19 & 27,1 & 3,386 & 1,311 & 6,714 & $*$ \\
\hline 42 & 4 & 7,1 & 10 & 14,3 & 24 & 34,3 & 13 & 18,6 & 18 & 25,7 & 3,414 & 1,2217 & 15,286 & ** \\
\hline 43 & 3 & 4,3 & 17 & 24,3 & 17 & 24,3 & 16 & 22,9 & 17 & 24,3 & 3,386 & 1,2193 & 10,857 & $*$ \\
\hline 44 & 5 & 7,1 & 9 & 12,9 & 21 & 30 & 17 & 24,3 & 18 & 25,7 & 3,4866 & $\begin{array}{l}1,12125 \\
1\end{array}$ & 12,857 & $*$ \\
\hline 45 & 4 & 5,7 & 14 & 20 & 17 & 24,3 & 19 & 27,1 & 16 & 22,9 & 3,4433 & 1,20978 & 9,857 & $*$ \\
\hline 46 & 4 & 5,7 & 13 & 18,6 & 24 & 34,3 & 13 & 18,6 & 16 & 22,9 & 3,3429 & 1,19037 & 14,714 & $*$ \\
\hline 47 & 7 & 10 & 19 & 27,1 & 17 & 24,3 & 18 & 25,7 & 9 & 12,9 & 3,0429 & 1,20909 & 8,857 & $* *$ \\
\hline 48 & 10 & 14,3 & 17 & $\begin{array}{l}2,1 \\
24,3\end{array}$ & 13 & $\begin{array}{l}24,3 \\
18,6\end{array}$ & $\begin{array}{l}18 \\
18\end{array}$ & 25,7 & 12 & 17,1 & 3,0714 & $\begin{array}{l}1,3332 \\
1\end{array}$ & 3,286 & \\
\hline 49 & 7 & 10 & 15 & 21,4 & 21 & 30 & 17 & 24,3 & 10 & 14,3 & 3,1193 & 1,19834 & 8,857 & $*$ \\
\hline 50 & 3 & 4,3 & 16 & 22,9 & 20 & 28,6 & 19 & 27,1 & 12 & 17,1 & 3,3 & $\begin{array}{l}1,1,338 \\
1,13\end{array}$ & 13,571 & $*$ \\
\hline & & & & ${ }_{p p<05}$ & & $*_{* p}^{* * 0}<01$ & & & & & & & & \\
\hline
\end{tabular}

\section{Discussion}

While there are several studies in literature indicating the application of Lean methods in educational contexts have a goof effect on education, almost all of these studies had limitations such as being held in one educational contexts (especially universities), being held in other sectors than education, having only the instructors and the employees perspectives not designed specifically for foreign language education. Thus, carrying out a study in public and private primary, middle, high schools and universities in Turkey and Iraq would be useful to answer the extent of the applicability of Lean methods in foreign language education from the perspective of the students in different socio-cultural environments. While conducting the interviews in Turkey, all the participants stated that they were familiar with Lean methods and their use in educational settings. The results of both the questionnaires and the interviews has showed that in order to achieve full-mastery of the target language Lean methods should be employed in the all of the learning processes in every educational institutions.

Over the past few decades, it has been seen that using authentic materials in language classrooms has a positive effect on students' foreign language achievement (Guariento \& Morley, 2001; Paltridge, 2001; Shrum \& Glisan, 2015). In addition it was concluded that authentic materials increase the learners' motivation towards the target language and they are also helpful in increasing student autonomy (Hyland, 2004; Otte, 2006; Thanajaro, 2000). Within this context Lean can be helpful for students and teachers, because Lean Educational Method supports the use of authentic and content related language materials both inside and outside the classrooms, so that added value could be achieved in language learning and teaching. Another important point which Lean can be extremely helpful is the implementation of the innovation of Content and Language Integrated Learning (CLIL). It is known that CLIL authentic context and meaningful communication opportunities (Ioannou Georgiou, 2012). 
However, the practice of CLIL can become a time-consuming, ineffective, and frustrating experience. Lean can help balance the overwhelming curriculum of CLIL and it can go beyond a fashionable approach that everybody wants to do it. In other words, with the help of Lean, both the teachers and the students may execute the learning process in a better way and at the same time Lean can enrich the motivation of all of the school's participants (Sugita McEown \& Takeuchi, 2014). Moreover, it has been found out that learning styles play a major role in language education and it is a must to identify students' learning styles when designing effective lessons and logical language teaching programs (Inal, Büyükyavuz \& Tekin, 2015). If learning styles are taken into account in the creation of language learning procedures, an opportunity of equal education can be provided to learners, so from this perspective Lean can bring equality to language education, because in its nature Lean respects every individual and the learning preferences of them. The implementation of information and communication technology (ICT) to language learning and teaching plays a major role in language classrooms (Razali, 2016). Therefore, the technology has inspired the learners' leaning styles, so in order to be Leaner in educational services ICT should be used in a broader level in educational institutions.

\section{Conclusions}

The results have been showed that there are some differences in students' considerations about Lean methods employed in the learning process of the target language. No matter how various considerations students have, the most important factor that can affect their mastery of the target language is the application of these related Lean methods in language learning process. Therefore, deficiencies in the implementation of the Lean methods in the foreign language learning process may intimidate the full acquisition of the language. A lot of reasons can be listed for it. First, the lack of awareness in both the teachers and the students about the preparation work, which should be done before the language classes, indifference to beneficial language learning activities, lack of necessary teaching materials in institutions etc. In other words, when the considerations are evaluated, it can be easily seen that quest for better language learning and teaching practices have been disregarded. This is the explanation of why ELT has witnessed the 'methodological changes', not the 'methodological innovations' up to now (LarsenFreeman \& Anderson, 2013). The recent and the dramatic situation of the education level of English in our country is the evidence of it. Blaming others and resistance the change, when students fail in public exams or the curriculum is not completed, are good examples of our biggest bad habits in education. As educators we should immediately quit this addiction, and make our society reach the level of contemporary civilization in language education by using Lean methods which are based on continuous improvement and innovations.

\section{Ethics Committee Approval}

The author confirms that the study does not need ethics committee approval according to the research integrity rules in their country. (Date of Confirmation: 12.03.2020)

\section{Acknowledgement:}

I would like to thank Hunar Nasuh Faraj,Jiwan Kamal Anwer, Vasıf Karagücük and Hala Hawa for their support. 


\section{References}

Afshar, H. S., \& Bagherieh, M. (2014). An Evaluation of Grammar and Vocabulary ConsciousnessRaising Activities in Current ELT Materials. Procedia-Social and Behavioral Sciences, 136, 109-113.

Arkoudis, S. (2006). Negotiating the rough ground between ESL and mainstream teachers. International Journal of Bilingual Education and Bilingualism, 9, 415-433.

August, D., \& Hakuta, K. (Eds.). (1997). Improving schooling for language-minority $\quad$ children: $\quad A$ research agenda. Washington, DC: National Academic Press.

Bailey, K. (2001). Action research, teacher research, and classroom research in language teaching. In M. Celce-Murcia (Ed.), Teaching English as a second or foreign language $\quad\left(3^{\text {rd }}\right.$ ed., pp.489-499). New York: Heinle \& Heinle.

Bell, D. (2003). Method and postmethod: Are they really so incompatible? TESOL Quarterly, 37,325336.

Broughton, G, Brumfit, C. Flavell, R. Hill, P., and Pincas, A.(2003). Teaching English as a foreign language. USA: Taylor and Faranchise e-library.

Brown, H. D. (2007). Teaching by Principles An Interactive Approach to Language Pedagogy.NewYork: Pearson.

Cleary, B. A., \& Duncan, S. J. (1997). Tools and techniques to inspire classroom learning. ASQC Quality Press.

Cleary, B. A., \& Duncan, S. J. (2008). Thinking tools for kids: An activity book for classroom learning. ASQ Quality Press.

Connell, D. (2005). Brain-based strategies to reach every learner: Surveys, questionnaires, and checklists that help you identify students' strengths-plus engaging brain-based lessons and activities teaching strategies Washington.DC: Teaching Strategies.

Creese, A. (2002). The discursive construction of power in teacher partnerships: Language and subject specialists in mainstream schools. TESOL Quarterly, 36, 597-616.

Davidson, C. (2006). Collaboration between ESL and content teachers: How do we know when we are doing right? International Journal of Bilingual Education and Bilingualism, 9, 454-475.

Dennis, P. (2007). Getting the right things done: a leader's guide to planning and execution. Lean Enterprise Institute.

DuFour, R., \& Eaker, R. (2005). Professional learning communities at work tm: best practices for enhancing students' achievement. Solution Tree Press.

Eaker, R., \& DuFour, R. (2015). Getting started: Reculturing schools to become professional learning communities. Solution Tree Press.

Ewy, R (2009). Stakeholder-driven strategic planning in education: A practical guide for developing and deploying successful long-range plans. ASQ Quality Press.

Fitzgerald, R. (2006). Smart teaching:Using brain research and data to continuously improve learning (Vol. 1). Asq Press.

George, M. L., \& George, M. (2003). Lean six sigma for service (p. 273). New York, NY: McGrawHill. 
Guariento, W., \& Morley, J. (2001). Text and task authenticity in the EFL classroom. ELT journal, 55(4), 347-353.

Harper, C., \& de Jong, E. (2004). Misconceptions about teaching English language learners. Journal of Adolescent and Adult Literacy, 48, 152-162.

Hedgcock, J. S. (2002). Toward a socioliterate approach to second language teacher education. The Modern Language Journal, 86(3), 299-317.

Hyland, F. (2004). Learning autonomously: Contextualising out-of-class English language learning. Language Awareness, 13(3), 180-202.

Inal, S., Büyükyavuz, O., \& Tekin, M. (2015). A study on preferred learning styles of Turkish EFL teacher trainees. Australian Journal of Teacher Education, 40(3), 4.

Ioannou Georgiou, S. (2012). Reviewing the puzzle of CLIL. ELT journal, 66(4), 495-504.

Jenkins, L. (2003). Improving student learning: Applying Deming's quality principles in classrooms. ASQ Quality Press.

Jenkins, L. (2013). Permission to forget: and nine other root causes of America's frustration with education. ASQ Quality Press.

Jenkins, L., Roettger, L. O., \& Roettger, C. (2007). Boot camp for leaders in K-12 education:Continuous improvement. ASQ Quality Press.

Johnson, K. (1999). Understanding language teaching: reasoning in action. New York: Heinle \& \& Heinle.

Kumaravadivelu,,B. (2006). Understanding language teaching: From method to post-method.Mahwah, NJ: Lawrence Erlbaum Associates.

Lai, C., \& Gu, M. (2011). Self-regulated out-of-class language learning with technology. Computer Assisted Language Learning, 24(4), 317-335.

Larsen-Freeman, D., \& Anderson, M. (2013). Techniques and Principles in Language Teaching 3rd edition. Oxford university press.

McKay, S. (2006). Researching second language classrooms. Mahwah, NJ: Lawrence Erlbaum Associates.

Menken, K, \& Antunez, B. (2001). An overview of the preparation and certification of teachers working with limited English proficiency (LEP) students. Washington, DC: Office of Bilingual Education and Minority Languages Affairs. (ERIC Document Reproduction Service No. ED455231)

Murphy,J. \& Byrd, P. (2001). Understanding the courses we teach: Local perspectives on English language teaching. Ann Arbor: University of Michigan Press.

Nunan, D. (1997). Research Methods in Language Learning. USA: Cambridge University Press.

Otte, J. L. (2006). Real language for real people: A descriptive and exploratory case study of the outcomes of aural authentic texts on the listening comprehension of adult English-as-a-second language students enrolled in an advanced ESL listening course.

Paltridge, B. (2001). Genre and the language learning classroom. University of Michigan Press.

Patton, M. Q. (1990). Qualitative evaluation and research methods. California: Sage Publications. 
Peercy, M. M. (2011). Preparing English language learners for the mainstream: Academic language and literacy practices in two junior high school ESL classrooms. Reading \& Writing Quarterly, 27(4), 324-362.

Pickard, N. (1995). Out-of-class language learning strategies: Three case studies. Language Learning Journal, 12(1), 35-37.

Razali, N. N. F. M. (2016). The Importance and Efforts in Using Technology to Improve Language Teaching and Learning and the Teacher's Readiness for Integrating ICT in the Classroom in Malaysian Education. Journal of Education and Social Sciences, 5(2), 227-230.

Shrum, J. L., \&Glisan, E. W. (2015). Teacher's handbook, contextualized language instruction.Cengage Learning.

Sugita McEown, M., \& Takeuchi, O. (2014). Motivational strategies in EFL classrooms: how do teachers impact students' motivation? Innovation in Language Learning and Teaching, 8(1), 20-38.

Thanajaro, M. (2000). Using authentic materials to develop listening comprehension in the English as a second language classroom (Doctoral dissertation, Virginia Tech).

Vural, H. (2013). Use of literature to enhance motivation in ELT classes. Mevlana International Journal of Education, 3(4), 15-23.

Ziskovsky, B., \& Ziskovsky, J. (2010). Optimizing Student Learning: A Lean Systems Approach to Improving K-12 Education. ASQ Quality Press.

\section{Yenilikçi Yalın Yöntemin yabancı dil öğreniminde incelenmesi}

\section{$\ddot{\mathbf{O} z}$}

İngilizce öğretme ve öğrenme sorusu bir asırdan fazladır İngiliz Dili Eğitimi akademisyenlerinin meşguliyeti haline gelmiştir. Dilbilgisi-Çeviri Yöntemi'nin ortaya çıkışından bu yana araştırmacılar, öğretmenler ve akademisyenler öğrencileri için en iyi yöntemi bulmaya çalışmıştır. Diğer bir deyişle, bu süreç bir asırlık sorgulama olarak tanımlanabilir. Aslında, bazı yöntemler dil yeterliliğinde belli bir miktarda başarılı olmuşlardır; ancak bunların birçoğu verimli öğrenmenin bereketli topraklarına ulaşamamıştır ve bunların hiçbiri her çeşit öğrenci tamamen uygun değildir. Bu sorunun arkasında birkaç neden vardır ve bunlardan biri öğrencilerin bu yöntemlerin yaratılmasına katkısı olabilir. Bu yöntemlerin, yani yeniliklerin, öğrencilerin yabancı dil öğrenimine hâkim olması amacıyla yaratılmış olmalarına rağmen, öğrencilerin İngilizce derslerinde kullanılan bu yöntemler hakkında nasıl hissettikleri nadiren sorgulanmıştır. Bu araştırma temel olarak nicel deseni kullanarak Türkiye ve Irak'taki 3 üniversite, 5 lise, 2 ortaokul ve 1 ilkokuldan rastlantısal olarak seçilen 975 öğrencinin bakış açısından yenilikçi yalın yönteme yönelik İngilizce öğretiminin uygunluğunu analiz etmek için tasarlanmıştır. Çalışma kapsamında öğrencilerin yenilikçi Yalın Eğitim yöntemine yönelik tutum ve görüşleri ortaya konmuş ve özellikle yabancı dil öğretmenleri ve araştırmacılar için bazı öneriler geliştirilmiştir.

Anahtar sözcükler: Yenilikçi Yalın Eğitim Yöntemi, Yabancı Dil Öğrenimi, İngiliz Dili Öğretimi. 


\section{AUTHOR BIODATA}

Filiz Yalçın Tilfarlıŏlu is a professor at University of Gaziantep, Faculty of Education, Department of Foreign Language Education. Her areas of professional interest included ELT methodology, classroom research, discourse analysis, testing and assessment. 